\title{
Expressions of Antimicrobial Peptide Gallinacin-1,-2 and-3 mRNAs in the Oviduct of Laying Hens
}

\author{
Hiroki Ohashi, Kalpana Subedi, Masahide Nishibori, \\ Naoki Isobe and Yukinori Yoshimura \\ Graduate School of Biosphere Science, Hiroshima University, Higashi-Hiroshima \\ 739-8528, Japan
}

\begin{abstract}
The aim of this study was to determine the profiles of mRNA expressions of gallinacin (Gal)-1, -2 and -3 , which are the antimicrobial peptides, in the oviduct of laying hens. The oviductal tissues of White Leghorn laying hens were collected. Expressions of Gal-1, -2 and -3 mRNA were examined by semiquantitative RT-PCR and localized in the vagina by in situ hybridization. The expressions of Gal-1, -2 and -3 were observed in infundibulum, magnum, isthmus, uterus and vagina by RT-PCR. The expressions of Gal-1, -2 and -3 were greater in the infundibulum and vagina, except for Gal-2 in the vagina. The signals of each Gal mRNA were identified in the basal cells of surface epithelium of vagina. These results suggested that antimicrobial peptide, Gal-1, 2 and -3 were expressed in the oviduct with a greater expression in the infundibulum and vagina, and surface epithelium were the major site for the synthesis of Gals in the vagina.
\end{abstract}

Key words : antimicrobial peptide, chicken, gallinacin, oviduct, mRNA expressions

\section{Introduction}

Defensins are endogenous peptides that contribute to the antimicrobial properties, and three defensin subfamilies ( $\alpha, \beta$ and $\theta$-defensins) exist in vertebrates (Sugiarto and $\mathrm{Yu}, 2004)$. In birds, only $\beta$-defensin have been found (Bensch et al., 1995 ; Sugiarto and $\mathrm{Yu}, 2004$; Xiao et al., 2004). The antimicrobial activities spectra of defensins include Gram-positive and Gram-negative bacteria, protozoan, some fungi and enveloped virus (Evans et al, 1994, 1995 ; Sugiarto and Yu, 2004). Until now a total of 13 different $\beta$-defensins designated as gallinacin (Gal)-1 to -13 are reported in chicken genome, whereas Gal-1, -2 and -3 were identified before the discovery of sequences of Gal-4 to -13 (Harwig et al., 1994 ; Brockus et al., 1998 ; Zhao et al., 2001 ; Lynn et al., 2004 ; Xiao et al., 2004). The immunity of hen oviduct is essential to protect the oviductal tissues from infection and bacterial contamination of eggs. The presence of immunocompetent cells including antigen presenting cells, $\mathrm{T}$ and $\mathrm{B}$ cells that play in the acquired immunity has been reported (Yoshimura et al., 1997 ; Zheng et al., 1997, 1998). Their population in the oviduct was increased in laying hens compared with immature ones under the effect of estrogen (Zheng et al., 1998). They were more

Received : June 6, 2005, Accepted : July 21, 2005

Correspondence should be addressed to : Y. Yoshimura, Graduate School of Biosphere Science, Hiroshima University, Higashi-Hiroshima 739-8528, Japan.

Tel and Fax : +81-82-424-7958 E-mail : yyosimu@hiroshima-u.ac.jp 
abundant in the two ends of oviduct, namely in the infundibulum and vagina (Yoshimura et al., 1997 ; Zheng et al., 1997, 1998). The immunity of the vagina may be most important within the oviduct for the protection from infection because it opens to cloaca where various microorganisms exist. However, little is known about the factors responsible in the innate immunity in the oviduct.

In mammals, it is suggested that vaginal epithelium has a powerful innate immune system, and antimicrobial peptide may play important roles in vaginal immune response and in the elimination of pathogens from the female reproductive tract (Pivarcsi et al., 2005). Recent studies have reported the expression of Gal-1 to -13 mRNA in the various organs of 2- or 3-month-old chickens that should be immature and before egg-laying (Zhao et al., 2001 ; Xiao et al., 2004). Zhao et al. (2001) did not find Gal$1,-2$ and -3 expressions in the oviduct of 3-month-old chickens. Xiao et al. (2004) found mRNA expression of Gal-8 to -13 , but not Gal-4 to -7 , in the oviduct of 2month-old chickens. As the population of immunocompetent cells changes in association with oviducal development during sexual maturation under an effect of estrogen (Zheng et al., 1997, 1998), the expression of Gals may also be different between immature and matured birds. However, the Gal mRNA expressions in the oviduct of laying hens have not been examined.

The goal of this study was to show the evidence and profiles of mRNA expressions of Gal-1, -2 and -3 in the oviduct of laying hens. In situ hybridization study was performed to localize their expressions in the vagina where the immunity is most important in the oviduct to eliminate the pathogenic agents.

\section{Materials and Methods}

\section{Birds and Tissues Collection}

White Leghorn hens laying five eggs or more in a sequence were kept in individual cages under a light regimen of $14 \mathrm{~h} \mathrm{~L}: 10 \mathrm{~h} \mathrm{D}$ and were provided with commercial feed and water ad libitum. The birds were euthanized by decapitation after $1-2 \mathrm{~h}$ of oviposition $(n=4)$. The oviducts were excised, and the tubular region of infundibulum, middle part of magnum, isthmus, uterus and vagina were collected for RT-PCR analysis. A part of vagina tissues were embedded in cryo-embedding medium (OCT compound ; Sakura Co., Tokyo, Japan) and snap-frozen in isopentane and solid $\mathrm{CO}_{2}$ mixture for in situ hybridization analysis. The experiments were done in agreement of the regulations of Hiroshima University for experiments on animals.

\section{Semi-quantitative RT-PCR}

1. Preparation of total RNAs

Total RNAs were extracted from the mucosal tissues of the infundibulum, magnum, isthmus, uterus and vagina using Sepasol RNA I Super (Nacalai Tesque, Inc. Kyoto, Japan) according to the manufacturer's protocol. The pellet of RNA was resuspended in TE buffer, treated with DNase 1 (Roche Diagnostics GmbH, Mannheim, Germany) at $37^{\circ} \mathrm{C}$ for $60 \mathrm{~min}$. The concentration was measured with Gene Quant pro (Amersham Pharmacia Biotec, U.K.) and stored at $-80^{\circ} \mathrm{C}$ until analysis.

2. RT-PCR 
The semi-quantitative RT-PCR was performed as described by our previous report (Chowdhury et al., 2004). The RNA samples were reverse transcribed using Rever Tra Dash (Toyobo Co. Ltd., Osaka, Japan) according to the manufacturer's protocol. The reaction mixture $(10 \mu \mathrm{l})$ consisted of $1 \mu \mathrm{g}$ of total RNA sample, $1 \times \mathrm{RT}$ buffer, $1 \mathrm{mM}$ each dNTP, 20 U RNase inhibitor, $0.5 \mu \mathrm{g}$ Oligo(dT)20, $50 \mathrm{U}$ Rever Tra Ace. The PCR was performed using Takara Taq ${ }^{\mathrm{TM}}$ (Takara Bio Inc., Shiga, Japan) according to the manufacturer's protocol. Primers used for PCR are shown in Table 1. The PCR mixture $(50 \mu \mathrm{l})$ contained cDNA corresponding to $1 \mu \mathrm{g}$ of the initial total RNA, $1 \times$ PCR buffer, $1.5 \mathrm{mM} \mathrm{MgCl}_{2}, 0.2 \mathrm{mM}$ each dNTP, $1.25 \mathrm{U}$ Takara Taq, $0.2 \mu \mathrm{M}$ each primer. Amplification of Gal-1, -2 and-3 cDNA was performed in a Programmable Thermal Controller PTC-100 (MJ Research Inc., Waltham, MA) under the following conditions : $94^{\circ} \mathrm{C}$ for $30 \mathrm{sec}$, then 35 cycles at $94^{\circ} \mathrm{C}$ for $30 \mathrm{sec}$ to denature, $58^{\circ} \mathrm{C}$ for 60 sec to anneal, $72^{\circ} \mathrm{C}$ for $90 \mathrm{sec}$ for the extension. The PCR for $\beta$-actin cDNA was carried out by a same manner except for annealing at $55^{\circ} \mathrm{C}$. In the preliminary experiment, different cycles of PCR, namely 30, 35 and 40 cycles, had been performed for standardization of PCR cycles in each sample. The PCR products were separated by electrophoresis on a $3 \%(\mathrm{w} / \mathrm{v})$ agarose gel containing $0.4 \%$ ethidium bromide. The density of each band on photographs was quantified using a Gel-Pro analyzer (Media Cybernetics, Silver Spring, MD), and Gal-1, -2 or $-3 / \beta$-actin ratio was obtained. The nucleotide sequence of PCR products of Gal-1, -2 and -3 were also determined using a BigDye terminator Sequence Kit (ver. 3.1, Applied Biosystems, Foster city, CA) with an ABI 3100 automated sequencer (Applied Biosystems, Foster city, CA). Sequences were analyzed with the G-PROF and GENETYX program packages (Genetyx Co. Ltd., Tokyo, Japan). The sequences of RT-PCR products of each Gal obtained in the current study corresponded to those reported in DNA data bank (Gal-1, 89-493 of nucleotide sequence in Acc. No. AF033335 ; Gal-2, 114-350 in Acc. No. AF 033336 ; Gal-3, 113-387 in Acc. No. NM 204650).

In situ Hybridization

1. Preparation of probes

Table 1. Primers for RT-PCR analysis of Gallinacin-1, -2 and -3 and $\beta$-actin and accession number used to design the primers

\begin{tabular}{lll}
\hline \hline Target & Primers & Accession number \\
\hline Gal-1 & F $: 5^{\prime}$-AAACCATGCGGATCGTGTACCTGC-3' & \multirow{2}{*}{ AF033335 } \\
& $\mathrm{R}: 5^{\prime}$-CAATGCTAAACTGCACACCTTTA-3' & \\
Gal-2 & F $: 5^{\prime}$-GTTCTGTAAAGGAGGGTCCTGCCAC-3' & \multirow{2}{*}{ AF033336 } \\
& $\mathrm{R}: 5^{\prime}$-ACTCTACAACACAAAACATATTGC-3' & \\
Gal-3 & $\mathrm{F}: 5^{\prime}$-CTGCCGCTTCCCACACATAG-3' & \multirow{2}{*}{ NM204650 } \\
& $\mathrm{R}: 5^{\prime}$-GCAATGCCAAACTGCACGCCTTTA-3' & \\
\multirow{3}{*}{-actin } & $\mathrm{F}: 5^{\prime}$-TGGATGATGATATTGCTG-3' & X00182 \\
& $\mathrm{R}: 5^{\prime}$-TTGCTCTGGGCTTCATCAC-3' & \\
\hline
\end{tabular}


The PCR products obtained by the RT-PCR for Gals as described above were used to prepare the probes labeled with digoxigenin. Digoxigenin labeling of PCR products was performed using a PCR DIG probe synthesis kit (Roche Molecular Biochemicals, Mannheim, Germany). The reaction mixture $(50 \mu l)$ contained $2 \mu l$ of PCR product (approximately $0.2 \mu \mathrm{g}$ ), $2.5 \mathrm{U}$ Takara Taq (Takara Bio Inc., Shiga, Japan), $1 \times$ PCR Dig probe synthesis mix, $1 \times$ PCR buffer, $0.2 \mu \mathrm{M}$ of each primer. The PCR conditions were the same as described above. The resulting DIG-labeled DNA products were separated by electrophoresis using a 3\% agarose gel, and isolated using DNA Gel Extraction kit (Millipore Co., Billerica, MA, USA). Then the products were precipitated using $4 \mathrm{M} \mathrm{LiCl}$ and ethanol and dried, followed by dissolving in $30 \mu \mathrm{TE}$.

2. In situ hybridization

Cryostat sections $(10 \mu \mathrm{m})$ of vagina were air-dried on the slides pretreated with $2 \%$ (v/v) 3-aminopropyl triethoxysilane (Sigma Co., St. Louis, MO, USA) in acetone. The sections were fixed with $4 \%$ paraformaldehyde (PFA) in phosphate buffered saline (PBS) for $10 \mathrm{~min}$. They were then treated with proteinase K (E. Merck, Darmstadt, Germany), $2 \mu \mathrm{g} / \mathrm{ml}$ in $100 \mathrm{mM}$ Tris- $\mathrm{HCl}$ with $50 \mathrm{mM}$ EDTA, $\mathrm{pH} 8.0$, at $37^{\circ} \mathrm{C}$ for 15 min. After brief washing in PBS, the sections were fixed again in 4\% PFA for $10 \mathrm{~min}$, and washed in PBS for 5 min. The slides were then immersed in $0.1 \mathrm{M}$ triethanolamine, $\mathrm{pH} 8.0$, containing $0.25 \%(\mathrm{v} / \mathrm{v})$ acetic anhydride for $20 \mathrm{~min}$. Then they were washed twice in PBS (10 min each), and dehydrated through successive baths of ethanol (70 to $100 \%)$ and air-dried. The sections were rehydrated with PBS, and then incubated at $37^{\circ} \mathrm{C}$ for $30 \mathrm{~min}$ with hybridization buffer [ $30 \mu \mathrm{l}$ of $100 \%$ deionized formamide, $20 \mu \mathrm{l}$ of $20 \times \mathrm{SSC}, 20 \mu \mathrm{l}$ TE, $5 \mu l$ of denatured salmon sperm DNA $(10 \mathrm{mg} / \mathrm{ml})$, and $10 \mu l$ of $\mathrm{H}_{2} \mathrm{O}$ ]. For the hybridization solution, $10 \mu l$ DIG-labeled PCR probes of Gal-1, -2 or 3 was added to $500 \mu l$ hybridization buffer. The hybridization solution was incubated at $100^{\circ} \mathrm{C}$ for $3 \mathrm{~min}$, then immediately cooled on ice for $10 \mathrm{~min}$. Sections were applied with the hybrididation solution and covered with a piece of parafilm, incubated in a humidified chamber at $37^{\circ} \mathrm{C}$ for $18 \mathrm{~h}$. After hybridization, slides were washed with $30 \%$ (v/v) formamide $/ 2 \times \mathrm{SSC}(20 \mathrm{~min} \times 2$ times $)$ and PBS containing $0.05 \%$ Tween (20 $\min )$ at $42^{\circ} \mathrm{C}$.

After equilibrating with buffer I $(0.1 \mathrm{M}$ Tris, $0.15 \mathrm{M} \mathrm{NaCl}, \mathrm{pH} 7.5)$ at room temperature for $5 \mathrm{~min}$, the slides were incubated with $5 \%(\mathrm{w} / \mathrm{v})$ blocking reagent (Boehringer Mannheim GmbH, Mannheim, Germany) diluted in buffer 1 at room temperature for $30 \mathrm{~min}$. Then the slides were incubated in a humidified chamber overnight at $4{ }^{\circ} \mathrm{C}$ with anti-DIG antibody conjugated with peroxidase (Roche Diagnostics GmbH, Mannheim, Germany) diluted to $1: 100$ in PBS containing 0.5\% (w/v) BSA. Finally, the immunoreactions were visualized by incubating the sections with a reaction mixture consisting of $0.02 \%(\mathrm{w} / \mathrm{v}) 3$, 3'-diaminobenzidine tetrahydrochloride and $0.005 \%$ (v/v) $\mathrm{H}_{2} \mathrm{O}_{2}$ in $0.05 \mathrm{M}$ Tris- $\mathrm{HCl}$ buffer, $\mathrm{pH}$ 7.6.

For the control staining, sections were incubated with hybridization solution containing no probes, followed by immunostaining using anti-DIG antibody. No signal was appeared in the control staining, suggesting the signals of Gal-1, -2 and -3 were specific (Data not shown). 
Statistical Analysis

Significance of differences in the Gal-1, -2 and $-3 / \beta$-actin ratio was examined by one-way ANOVA followed by Duncan's multiple range test (Duncan, 1955). Significance was accepted when the $\mathrm{P}$ value was less than 0.05 .

\section{Results}

The bands of PCR products for Gal-1, -2 and -3 were observed in all segments of oviducts including infundibulum, magnum, isthmus, uterus and vagina (Fig. 1 A). The expression of Gal-1 was greater in the infundibulum and vagina than magnum and isthmus, whereas Gal-2 mRNA expression was stronger only in the infundibulum than the other segments of oviduct. The Gal-3 mRNA expression was greater in the infundibulum and vagina than the other oviductal segments (Fig. 1 B). Figure 2 shows the expression of Gal-1, -2 and -3 in the vagina examined by in situ hybridization. The signals of each Gal mRNA were identified in many of the basal cells of surface epithelium in the mucosal folds (Fig. 2).

\section{Discussion}

We are reporting that mRNAs of antimicrobial peptide, Gal-1, -2 and -3 , were expressed in the oviductal mucosal tissue, and surface epithelial cells in the vagina showed signals for the expression. The expression of each type of Gal was stronger in the infundibulum and vagina than the other segments except for Gal-2 in the vagina.

Zhao et al. (2001) examined expressions of Gals in various tissues of a healthy 3-
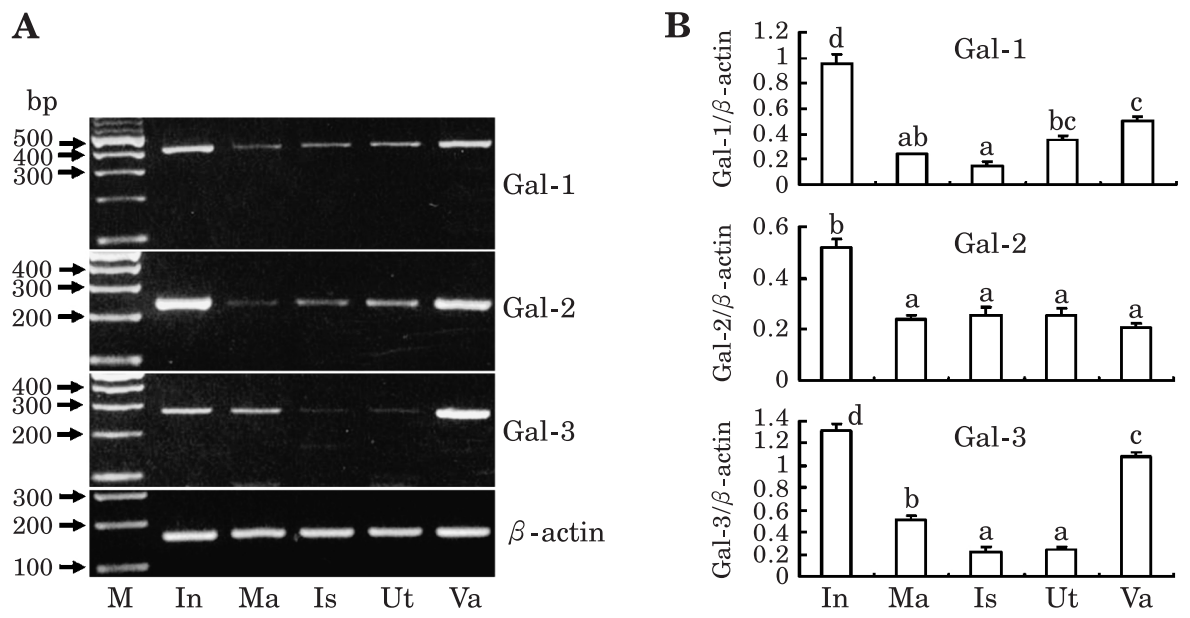

Fig. 1. RT-PCR of Gallinacin (Gal)-1, -2 and-3 in the oviduct of laying hen.

(A) RT-PCR products of Gal-1, -2 and-3. In=infundibulum, Ma=magnum, Is =isthmus, Ut=uterus, Va=vagina. (B) Semi-quantitative RT-PCR analysis of Gal-1, -2 and-3 mRNA expressions in the oviduct. The values are mean \pm SEM of densitometric values of Gal-1, -2 and-3 mRNA to $\beta$-actin mRNA ( $\mathrm{n}=4$ each). Values with different superscripts $(a, b)$ are significantly different $(\mathrm{P}<$ 0.05). 

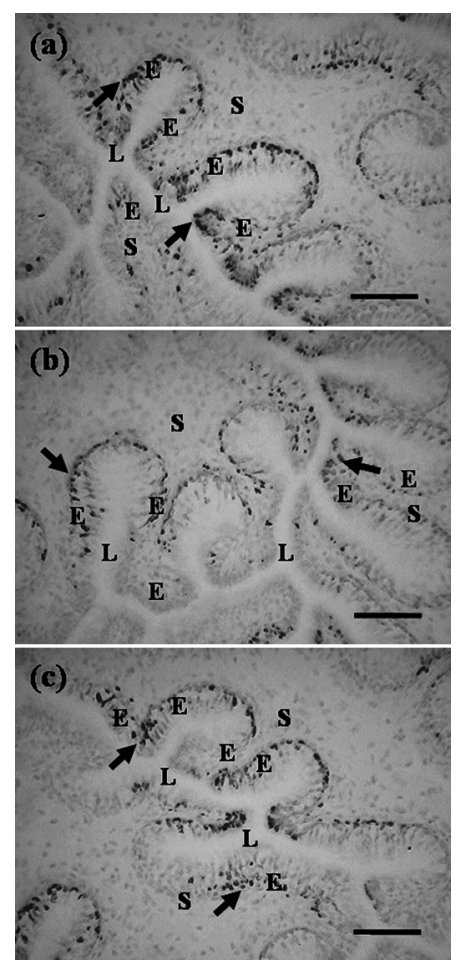

Fig. 2. In situ hybridization for gallinacin (Gal)-1, -2 and-3 mRNA expressions in the vagina.

(a), (b) and (c) show gallinacin -1, -2 and-3 mRNA expressions, respectively. Signals are found in the basal cells of surface epithelium (arrows). L= vaginal lumen, $\mathrm{S}=$ stroma. Scale $\mathrm{bar}=50 \mu \mathrm{m}$.

month-old chicken. They reported that Gal-1 and -2 were expressed strongly in healthy bone marrow and a lesser extent in lung. They also showed strong expression of Gal3 in tongue, bursa of Fabricius and trachea, moderate expression in the skin, esophagus and air sacs, and weaker expression in bone marrow, large intestine, kidney and ovary, suggesting that Gal-3 was expressed widely in nonmyeloid cells. They did not show expressions of Gal-1, -2 and -3 in the oviduct of 3-month-old chickens. However, the current study revealed that Gal-1, -2 and -3 mRNAs were expressed in all segments of oviduct. Thus, we assume that the expression of Gals occurs in the developed oviduct of laying hens, and gonadal steroids responsible in the oviductal development may be significant factors for this process.

The expressions of Gal-1, -2 and -3 mRNAs were greater in the infundibulum and vagina except for Gal-2 in the vagina. Because Gals have antimicrobial activities against Gram-positive and Gram-negative bacteria (Evans et al., 1994, 1995 ; Sugiarto and $\mathrm{Yu}, 2004$; Higgs et al., 2005), they may play the role in earlier defense against pathogenic agents as innate immunity in the oviduct. Previous studies showed that the populations of antigen presenting cells, $\mathrm{T}$ and $\mathrm{B}$ cells that are responsible in adaptive immunity were also greater in these two ends of oviduct (Yoshimura et al., 1997 ; 
Zheng et al., 1997, 1998). Thus it is likely that both innate immunity mediated by Gals and adaptive immunities are more developed in the two ends of oviduct, namely infundibulum and vagina.

In mammals, $\beta$-defensins promote adaptive immune responses by recruiting dendritic and T cells (Yang et al., 1999), and enhances IgG synthesis through affecting B and $\mathrm{T}$ cells interactions to link innate immunity with adaptive immune system (Lillard et al., 1999). Thus it is assumed that there may be a linkage between higher expression of Gal-1 and -3 and the greater population of immunocompetent cells (Yoshimura et al., 1997 ; Zheng et al., 1997, 1998) in the infundibulum and vagina in laying hens, although further studies are needed to confirm this theory.

The immunity in the vagina is most important for the defense system in the oviduct because it opens to cloaca where various microorganisms exist. The signal of Gal-1, -2 and -3 expressions were found in the basal cells of surface epithelium in the vagina. Out of Gal-1, -2 and -3 , only expression of Gal-2 was not higher in the vagina than in the magnum and isthmus. Thus, although the localization of the three types of Gals was same, there may be some difference in the factors controlling their expressions among them. In humans, $\beta$-defensin expression was localized in the surface epithelial layers of the vagina and other regions of genital tract (Quayle et al., 1998 ; Schaefer et al., 2005 ; Valore et al., 1998 ; Pivarcsi et al., 2005), and epithelial $\beta$-defensin may prevent microorganisms from entering surfaces and prevent the attack of microorganisms that have already entered the epithelia (Schroder, 1999). The cells expressing Gals are suggested to play a significant role in defending against pathogenic agents in the oviduct. Furthermore, eggs are rich source of antimicrobial protein/peptides such as lysozyme and ovotransferrin in egg-white (Pellegrini et al., 1997 ; Ibrahim et al., 2000 ; Mine et al., 2004). If the Gals are secreted from the epithelial cells to the vaginal lumen, they may be incorporated in the substances on the surface of egg-shell and play roles as antimicrobial factors. The expressions of Gals in the infundibulum may have some roles in elimination of foreign organisms. Although the possibility of the appearance of bacteria in this segment is unclear, sperms migrate and stay in this segments for fertilization in copulated or inseminated hens. Zheng et al. (1998) suggested that the infundibulum contains many immunocompetent cells, and they may play roles in the removal of not only bacteria but also sperms that did not participate in fertilization. The higher expression of Gals in the infundibulum may have roles resembled to those immunocompetent cells.

In conclusion, we suggest that expression of antimicrobial peptide, Gal-1, -2 and -3 occurred in the oviduct of laying hens with a greater expressions in the infundibulum and vagina compared with the other segments except for Gal-2 in the vagina. The surface epithelial cells of mucosa may be the major site for the synthesis of these peptides in vagina. The Gals probably play significant roles in innate immunity of the oviduct to defend against pathogenic agents.

\section{Acknowledgment}

This work was supported by a Grant-in-Aid for Scientific Research (No. 
14360169) from the Japan Society for the Promotion of Science (JSPS).

\section{References}

Bensch KW, Raida M, Magert HJ, Schulz-Knappe P and Forssmann WG. hBD-1 : a novel $\beta$-defensin from human plasma. FEBS Letters, $368: 331-335.1995$.

Brockus CW, Jackwood MW and Harmon BG. Characterization of $\beta$-defensin prepropeptide mRNA from chicken and turkey bone marrow. Animal Genetics, 29 : 283-289. 1998.

Chowdhury VS, Nishibori M and Yoshimura Y. Changes in the mRNA expression of TGF $\beta$ receptor types II and III in the anterior pituitary during induced molting in hens. Journal of Poultry Science, $41:$ 140-146. 2004.

Duncan BD. Multiple range and multiple F-tests. Biometrics, $11: 1-42.1955$.

Evans EW, Beach GG, Wunderlich $\mathbf{J}$ and Harmon BG. Isolation of antimicrobial peptides from avian heterophils. Journal of Leukocyte Biology, 56 : 661-665. 1994.

Evans EW, Beach FG, Moore KM, Jackwood MW, Glisson JR and Harmon BG. Antimicrobial activity of chicken and turkey heterophil peptides CHP1, CHP2, THP1, and THP3. Veterinary Microbiology, 47 : 295-303. 1995.

Harwig SS, Swiderek KM, Kokryakov VN, Tan L, Lee TD, Panyutich EA, Aleshina GM, Shamova OV and Lehrer RI. Gallinacins : cysteine-rich antimicrobial peptides of chicken leukocytes. FEBS Letters, 342 : 281-285. 1994.

Higgs R, Lynn DJ, Gaines S, McMahon J, Tierney J, James T, Lloyd AT, Mulcahy G and O'Farrelly C. The synthetic form of a novel chicken $\beta$-defensin identified in silico is predominantly active against intestinal pathogens. Immunogenetics, $57: 90-98.2005$.

Ibrahim HR, Sugimoto Y and Aoki T. Ovotransferrin antimicrobial peptide (OTAP-92) kills bacteria through a membrane damage mechanism. Biochimica et Biophysica Acta, 1523 : 196-205. 2000.

Lillard JW Jr, Boyaka PN, Chertov O, Oppenheim JJ and McGhee JR. Mechanisms for induction of acquired host immunity by neutrophil peptide defensins. Proceedings of the National Academy of Sciences of the United States of America, $96: 651-656.1999$.

Lynn DJ, Higgs R, Gaines S, Tierney J, James T, Lloyd AT, Fares MA, Mulcahy G and O'Farrelly C. Bioinformatic discovery and initial characterisation of nine novel antimicrobial peptide genes in the chicken. Immunogenetics, 56 : 170-177. 2004.

Mine Y, Ma F and Lauriau S. Antimicrobial peptides released by enzymatic hydrolysis of hen egg white lysozyme. Journal of Agricultural and Food Chemistry, 52 : 1088-1094. 2004.

Pellegrini A, Thomas U, Bramaz N, Klauser S, Hunziker P and von Fellenberg R. Identification and isolation of a bactericidal domain in chicken egg white lysozyme. Journal of Applied Microbiology, $82: 372-378.1997$.

Pivarcsi A, Nagy I, Koreck A, Kis K, Kenderessy-Szabo A, Szell M, Dobozy A, Kemeny L. Microbial compounds induce the expression of pro-inflammatory cytokines, chemokines and human $\beta$-defensin-2 in vaginal epithelial cells. Microbes and Infection, 7 : 1117-1127. 2005.

Quayle AJ, Porter EM, Nussbaum AA, Wang YM, Brabec C, Yip KP, Mok SC. Gene expression, immunolocalization, and secretion of human defensin-5 in human female reproductive tract. American Journal of Pathology, 152 : 1247-1258. 1998.

Schaefer TM, Fahey JV, Wright JA and Wira CR. Innate immunity in the human female reproductive tract : antiviral response of uterine epithelial cells to the TLR3 agonist poly (I : C). Journal of Immunology, 174 : 992-1002. 2005.

Schroder JM. Epithelial antimicrobial peptides : innate local host response elements. Cellular and Molecular Life Sciences, 56 : 32-46.1999.

Sugiarto $\mathrm{H}$ and $\mathrm{Yu}$ PL. Avian antimicrobial peptides : the defense role of $\beta$-defensins. Biochemical and Biophysical Research Communications, 323 : 721-727. 2004.

Valore EV, Park CH, Quayle AJ, Wiles KR, McCray PB Jr and Ganz T. Human $\beta$-defensin-1 : an antimicrobial peptide of urogenital tissues. Journal of Clinical Investigation, $101: 1633^{-}$ 1642. 1998.

Xiao Y, Hughes AL, Ando J, Matsuda Y, Cheng JF, Skinner-Noble D and Zhang G. A genome- 
wide screen identifies a single $\beta$-defensin gene cluster in the chicken : implications for the origin and evolution of mammalian defensins. BMC Genomics, 5 : 56. 2004.

Yang D, Chertov O, Bykovskaia SN, Chen Q, Buffo MJ, Shogan J, Anderson M, Schroder JM, Wang JM, Howard OM and Oppenheim JJ. $\beta$-Defensins : linking innate and adaptive immunity through dendritic and T cell CCR6. Science, $286: 525-528.1999$.

Yoshimura Y, Okamoto T and Tamura T. Localization of MHC class II, lymphocytes and immunoglobulins in the oviduct of laying and molting hens. British Poultry Science, 38 : 590-596. 1997.

Zhao C, Nguyen T, Liu L, Sacco RE, Brogden KA, Lehrer RI. Gallinacin-3, an inducible epithelial beta-defensin in the chicken. Infection and Immunity, $69: 2684-2691.2001$.

Zheng WM, Yoshimura Y and Tamura T. Effects of sexual maturation and gonadal steroids on the localization of IgG-, IgM- and IgA-positive cells in the chicken oviduct. Journal of Reproduction and Fertility, $111: 277-284.1997$.

Zheng WM, Yoshimura Y and Tamura T. Effects of age and gonadal steroids on the localization of antigen-presenting cells, and $\mathrm{T}$ and $\mathrm{B}$ cells in the chicken oviduct. Journal of Reproduction and Fertility, $114:$ 45-54. 1998. 